\title{
REVIEW ON NYCTANTHES ARBOR-TRISTIS (HARSINGHAR) - A HERBAL MEDICAMENT WITH SPECIAL REFERENCE TO UNANI MEDICINE
}

\author{
Azma $^{1}$, Waseem Ahmad ${ }^{1}$, Asim Ali Khan ${ }^{2}$ and Mohammad Fazil ${ }^{1 *}$ \\ ${ }^{1}$ Hakim Ajmal Khan Institute for Literary and Historical Research in Unani Medicine \\ ${ }^{2}$ Director General, Central Council for Research in Unani Medicine, Ministry of AYUSH, Govt. of India, New Delhi
}

\section{Review Paper}

Received: 05.06.2021

Revised: 12.06.2021

Accepted: 22.06.2021

\begin{abstract}
Nyctanthes arbor-tristis Linn is one of the important herbal drugs used for therapeutic purpose in India. It is described with the name 'Harsinghar' in Unani Medicine. Various parts of the plant are used medicinally to cure various diseases since centuries ago. These medicinal properties of the plant are due to the active phytochemicals present in the plant. Various chemicals have been isolated from this miracle plant having therapeutic potential possessing ethnomedical and pharmacological activities. It is a rich source of important phytochemicals like nycanthine, astringent principle, beta cortisol, coloring matter, tannins, flavonoids, cardiac glycosides, saponins and alkaloids etc. Pharmacological actions of Harsinghar include cholagogue, anthelmintic, laxative, antipyretic, diaphoretic, diuretic; for which the the plant is employed in the treatment of skin disorders, dandruff, malaria, different types of fever, hemorrhoids, palpitation, cough, excessive menstrual bleeding menstrual etc. Diverse pharmacological studies of the plant have been reported such as antimicrobial, anti-inflammatory, antidepressant, antipyretic, antioxidant activity proving the traditional claims scientifically. In this paper, an attempt has been made to summarize the information described in classical Unani texts and updated scientific research conducted on different parts of the $N$. arbor-tristis plant.
\end{abstract}

No. of Pages: 8

References: 49

Keywords: Nyctanthes arbor-tristis, Unani medicine, Night jasmine, therapeutic uses.

\section{INTRODUCTION}

Unani System of medicine is one of the ancient traditional system of medicine originated from Greece and based on the theoretical framework of Greek physician Hippocrates. It passed through many stages, countries, cultures and people. It is developed by Romans, Arab physicians and when it reached in India during Mughal period also enriched by Indian physicians. According to basic concepts of Unani medicine, there is a power of self-preservation and/or adjustment in an individual which is called defense constitution which gets affected in diseased conditions and needs restoration to normal by the use of various therapies prescribed in the system ${ }^{1}$. In Unani literature, four types of therapies are described for maintaining health and treating diseases. These four therapies are Ilaj bil-Tadbeer (Regimental therapy), Ilaj bil-Ghiza, (Dietotherapy), Ilaj bilDawa (Pharmacotherapy) Ilaj bil-Yad (Surgery) ${ }^{2}$. Pharmacotherapy involves administration of drugs to correct the disease. As per World Health Organization, $80 \%$ of the world population prefers or uses Herbal medicine for primary health care. In Unani medicine, the use of drugs employed are mainly derived from plants, for prevention and cure of

*Corresponding author: fazilmd00@gmail.com 
ailments is based on the concept of holistic healing considering the individual's psycho-physical wellbeing. Drug identification, action, uses of Mufradat (single drugs) and preparation of Murakkabat (compound drugs) are selected according to the temperament of the patient and nature of the disease. Single drugs or their combinations in raw form are preferred over compound drugs ${ }^{3}$. Most of the naturally occurring drugs used in this system are safe for human use, while drugs that are toxic in crude form are first processed and purified in many ways before use to make them safer ${ }^{4}$. In Unani system of medicine, numerous plant origin drugs are mentioned for medicinal purpose ${ }^{5}$ and it also has a unique feature of adding Musleh (corrective drug) to counter the Muzzirrat (harmful effect/toxicity) of main drugs. The plant Nyctanthes arbor-tristis Linn., commonly known as Harsinghar, is described in Unani medicine for its multi-potential pharmacological activities. It is also known for its traditional uses by the rural, mainly tribal people of India ${ }^{6}$. The generic name Nyctanthes derived from two Greek words- 'Nykhta'-Night and 'anthos'-flower, and specific name 'arbor-tristis' means sad tree is supposed to be derived from dull appearance of the plant during daytime ${ }^{7}$. It is native to India and found abundant in outer Himalayan ranges from the Chenab to Nepal, Assam, Bengal, southwards to the Godavari and also found in Kanchanaburi province in Thailand $^{8,9}$. It is found wild in the forest of Central India ${ }^{10,11}$ and also commonly planted in the gardens for beautif ul and fragrant flowers. Flower resemble with the jasmine flower ${ }^{12}$. Nyctanthes arbor-tristis plant has multi- purpose uses. It is used for therapeutic purpose. An essential oil is present in the flower which is used in perfumery. Garland of flower is worn around the neck and pinned in hair as gajra by women to enhance for beautification so called Harsinghar ${ }^{12}$. Juice is obtained from the flower and stalk, and preserved in a concentrated form as a purple dye ${ }^{12}$. Besides, it has revealed strong prospective as a safe and natural coloring agent due to the manifestation of natural pigment 'nyctanthin' which can supplementary be applied in food and textile industries ${ }^{13}$.

\section{Description of the plant}

N. arbor-tristis Linn. (NAT) is a small tree or shrub growing upto 15-20 feet tall with a grey flaky bark. It is a very popular flowering plant in warm, humid regions. It has somewhat square shaped stem and shoots. Stem bark is brown, rough and white spots are found on it $^{14}$. Leaves are 4-sided, opposite, short petioled, quadrate or oblong, moderately thick, rough, pointed or coarsely serrate, scabrous, dark green in colour, can be easily broken, having abundant veins and lower surface is thicker than the upper surface ${ }^{15}$; panicles terminal composed of small six-flowered terminal umbellets, calyx campanulate, slightly 5-notched, downy; corolla tube cylindric as long calyx, segment 5-7; involucel of fourcordate, opposite, sessile leaflets; Flowers are numerous, small, soft, fragrant, have 6-8 white petals resembling with jasmine flower, which are arranged on a reddish tubal stalk ${ }^{12}$. This plant blooms during spring; and the plethora of bloom is so much that they are hardly ever without a flower during their blooming cycle ${ }^{14}$ and it should be grown in a bright sunny spot in warm temperatures to thrive ${ }^{14}$. Flowers open towards the evening to night and fall in the morning. The fallen flowers look like a decorative carpet. Fruit/ is a dry, oblong, mucronate capsule, prominently veined, $1.25 \mathrm{~cm}$ long and 1 . $25 \mathrm{~cm}$ wide, unripe green colored, ripe in summer season and become brown, compressed, 2-celled, each of which contains a yellowish brown, thin, flat, elevated in the centre, foliaceous seed kernel of the seed is white, bitter or tasteless and astringent ${ }^{10,14,16}$.

\section{Scientific classification ${ }^{10,17}$ :}

Kingdom: Plantae; Division: Magnoliophyta; Class: Magnoliopsida; Order: Lamiales; Family Oleaceae; Genus: Nyctanthes; Species: arbor-tristis, Binomial name: Nyctanthes arbor-tristis

\section{Vernacular Names ${ }^{10,14,15,17,18}$ :}

English: Weeping Nyctanthes, Night Jasmine, Coral Jasmine, Tree of Sorrow

Urdu/ Unani /Persian: Harsinghar, Haarsinghar, Hadsinghar, Had jora

Sanskrit: Sephalika, Parijataka, Parijata, Rajanihassa (night smiling) and Atyuha (very sensitive)

Bengali: Sephalika, Seoli, Sheoli,

Hindi: Siharu, Harsinghar;

Marathi: Kharbadi, Kharassi, Khurasli, Partaka;

Tamil: Manja- Pavelam;

Kannada: Harsin;

Telugu: Poghada, Pagadamalle, Parijat, Sepali,

Punjabi: Pakura,

Oriya: Godokodiko, Gunjoseyoli, Singaraharo, Gujarati: Jayaparvati, Parijatak, Par Booti,

Oriya: Godokodiko, Gunjoseyoli, Singaraharo

\section{Mustamil Juz (Part used):}

Flowers, flower stalk and leaves ${ }^{12,18}$

Flower, seeds, leaves, bark, fruit and gum ${ }^{11,14,19}$

\section{Phytochemistry:}

Phytochemistry of $N$. arbor-tristis has revealed the presence of diverse group of chemical constituents in different part of the plant. Flower yields steroids, carbohydrates, flavonoids and alkaloids apigenin, anthocyanin, D-mannitol, tannin, glucose, carotenoid, Essential Oil, Kaemferol, Nyctanthin, Glycosides, Quercetin, Rengylone, $\alpha$-crocetin (or crocin-3), $\beta$-monogentiobioside, $\beta$ monogentiobioside- $\beta$-D, $\beta$ digentiobioside. Oil extracted from flower contains alphapinine, p-cymene, 1-hexanol methyl heptanone, phenyl acetaldehyde, 1-deanol and anisaldehyde. Alkaloids and glycosides contents are found in the bark ${ }^{17}$. Leaves contain 
alkaloid nyctanthine along with nannitol, $\beta$-Amyrin, $\beta$ Sitosterol, hentriacontane, benzoic acid, mannitol, nycanthoside $^{16}$, astragalin, nicotiflorin, oleanolicacid, nyctanthic acid, friedelin, lupeol, astringent, resinous substances, ascorbic acid, coloring matters, sugar, and traces of an oily substance, tannic acid, methyl salicylate, carotene, an amorphous resin and traces of volatile oil ${ }^{10,20,21}$. Stem contains glycosides naringenin, 4-0-beta-glucapyranosylalpha-xylopyranoside and sitosterol. Many alkaloids, tannins and glycosides, and beta-sitosterol and oleanic acid have been isolated from the chloroform extract of the root. Seed contains Phytosterols, phenolic compounds, tannins, flavonoids, cardiac glycosides, saponins and alkaloids, arbortristosides A \& B, nyctanthic acid, nyctanthoside ${ }^{16}$.

\section{Mizaj (Temperament)}

Gul (flower) - Barid- Yabis (Cold, Dry) ${ }^{12,19}$; Haar-2, Yabis (Hot-2, Dry) ${ }^{18}$

Qummah (flower stalk) - Haar-2, Yabis ((Hot-2, Dry) $)^{14}$

Barg (Leaf) - Haar, Yabis-1 (Hot, Dry-1) ${ }^{19}$; Barg (Leaf) and Chhal (Bark) - Barid (cold) $)^{14}$

\section{Muzir (Harmful effect):}

It may cause Sual (cough) ${ }^{19}$ but most of the physicians mentioned that it useful in cough and bronchitis/bronchial asthma $^{14,18}$.

\section{Musleh (Correctives): \\ Katira (Astragalus gummifer) ${ }^{19}$}

Badal (Substitute):

Kutki (Picrorhiza kurroa) ${ }^{19}$

Miqdar (Dose): 1-2 gm ${ }^{11}$

Murakkabat (compound): Habb-i Harsinghar ${ }^{4}$

\section{Afaal (Pharmacological Actions):}

Flower and stalk are Mufarreh (exhilarant), Muqawwi-i Hawaas (tonic for senses), Muqawwi-i Qalb (heart tonic) $)^{12,14,18}$, Daf-i Bukhar (antipyretic) ${ }^{11,16}$ (Munaffis-i Balgham (expectorant), Mukhrij-i Safra wa Riyah ${ }^{15,18}$, Muqawwi-i Bah (aphrodisiac) ${ }^{11,12}$; leaf is Musaffi (blood purifier), Mudir-i Baul (diuretic) ${ }^{14}$, Mushil-i Balgham (purgative of phlegm), Mushil-i Safra (cholagogue), Muqawwi-i Meda (stomachic) ${ }^{14}$, Kasir-i Riyah (carminative) $)^{14}$, Mulaiyyin (laxative) ${ }^{12,14}$, Daf-i Daad (antifungal) ${ }^{12,14,15}$, Qatil-i Deedan (Anthelmintic) ${ }^{14,18}$, Habis (astringent) $^{14}$, Muwallid-i Araq (diaphoretic) ${ }^{11,14}$, Muhallil-i Waram (anti-inflammatory) ${ }^{16}$. Root and gum are Qawi Muqawwi-i Bah (strong Aphrodisiac) ${ }^{11,14}$.

\section{Istemal (Therapeutic Uses):}

Quba (Ringworm) $)^{11,12}$, Bawaseer (haemorrhoids) ${ }^{11.19}$, Yarqan (jaundice $^{12,18}$, Khafaqan Haar (palpitation of hot type) $)^{18}$, Khafaqan (palpitation) ${ }^{14}$ and Fasad-i Dam (blood impurities) $^{14}$, Humma Muzmin (chronic fever) ${ }^{14,18}$, Humma Murakkab (compound fever) ${ }^{12,14}$, Jhaeen (freckles), Chheep/Behaq (ptyriasis), Waja al-Mafasil (arthritis) ${ }^{14}$, Sual Yabis (dry cough) $)^{14,18}$, Niqris (gout) ${ }^{14}$, Khala (fracture) ${ }^{12,14,15,18}$, Deedan-i-Ama (intestinal worm) ${ }^{14}$. Amraz-i Halaq wa Tanaffus (diseases of throat and respiratory system) ${ }^{18}$, Irq alNasa (sciatica), Humma (fever) and Waja al-Mafasil (rheumatism) $^{8,10}$, malaria ${ }^{16}$, filarial fever ${ }^{16}$, cold and cough ${ }^{16}$, bronchitis $^{16}$ and Amraz-i Ayn (eye diseases) ${ }^{14}$.

\section{Remedies prepared with different parts of Nychathes arbor-tristis for various diseases:}

Remedies prepared with different parts of Nychathes arbortristis are used to cure various diseases. Naqoo (diffusion) of flower is beneficial for haemorrhoids ${ }^{11}$; Joshanda (decoction) of flowers is useful for the treatment of arthritis; Gul Qand (semi-solid preparation of petals and sugar) $12 \mathrm{gm}$ is taken orally in the morning as heart tonic and to cure palpitation $^{14,18}$. Flower oil is effective in fracture ${ }^{18}$. Seed are highly beneficial for dandruff ${ }^{12}$ and are also useful the treatment of piles and skin diseases ${ }^{18,22}$. seed kernel-12 gm are ground with 3 gm of black pepper, and gram sized piles are prepared, $3 \mathrm{gm}$ along with cold water, is taken in the morning $^{16,18}$ for 7 days $^{14}$ in case of haemorrhoids; paste prepared with seeds and water, topically applied on scalp, is an effective remedy for dandruff ${ }^{11,12}$ and also used topically in case of pityriasis and freckles ${ }^{14}$. Leaf is Muqawwi-i Meda (stomachic) and is added in food recipes. Naqoo ((diffusion) of leaf is diuretic ${ }^{14}$, Ras (leaf juice) is diuretic, laxative and anthelmintic $^{14}$; it is used with Shehad (honey) for chronic fever and cough; with Misri (sugar crystal) for the treatment of bilious diseases; and with Namak (salt) for helminthiasis; fresh leaf juice is safe to use in infants as laxative ${ }^{11,12}$, Matbookh (decoction) of leaf is used as antipyretic and harmless laxative for children ${ }^{9}$; leaf decoction with Maweez (Vitis vinifera) is beneficial for bilious fever; Joshanda (decoction) prepared with the leaves, young shoots of Neem (Azadirachta indica A. Juss) $)^{8-10}$, is beneficial for malaria when used in a dose of $5 \mathrm{ml}$ twice daily, for 3 days $^{16}$; oral administration of leaf decoction is useful for fever and sciatica $^{10}$; leaf extract is antihistaminic, tranquilizing and purgative $^{23}$; for chronic fever, few new leaves are ground with water and used along with juice of Zanjabeel/ adrak (rhizome of Zingiber officinalis) avoiding the milk, fish and meat products during treatment $\mathrm{t}^{12,14,18}$; fresh leaves are astringent and used with black pepper, to check the excessive menstrual bleeding $^{14}$; moreover, paste prepared with leaves applied topically has been found effective for ringworm ${ }^{12,18}$ and is also beneficial for other skin diseases like freckles and ptyriasis ${ }^{14}$. Some amount of bark and 5 black peppers, are ground with 
water and used orally, for bleeding and non-bleeding hemorrhoids ${ }^{14,18}$; paste prepared with bark, Kanji (alcoholic preparation), oil, and Saindha Namak (rock salt) is beneficial in various ophthalmic disorders when applied externally over the eye ${ }^{14} ; 5$ grains of bark is eaten with betel-nut and leaf, for expectoration of thick phlegm ${ }^{10}$. Fruit is useful for respiratory ailments; 3-4 fruits are ground and used orally with lukewarm water twice daily as full dose for cough and bronchitis for 5 days for 40 days respectively ${ }^{16}$.

\section{Scientific Studies}

\section{Anti-inflammatory activity:}

Various studies reported that Nyctanthes arbor-tristis plant possesses anti-inflammatory activity. Saxena et al. reported anti-inflammatory activity of Nyctanthes arbor-tristis. In this study the water-soluble portion of the alcoholic extract of the leaves of Nyctanthes arbor-tristis (NAT) was screened for the presence of anti-inflammatory activity. NAT inhibited the acute inflammatory oedema produced by different agents, viz. carrageenin, formalin, histamine, 5-hydroxytryptamine and hyaluronidase in the hindpaw of rats. The acute inflammatory swelling in the knee joint of rats induced by turpentine oil was significantly reduced. In subacute models, NAT was found preventing granulation tissue formation in the granuloma pouch and cotton pellet test. Acute and chronic phases of formaldehyde induced arthritis were inhibited significantly. NAT was also found to inhibit the inflammation produced by immunological methods, viz. Freund's adjuvant arthritis and PPD induced tuberculin reaction ${ }^{24}$. Another study conducted by Omkar et al. has reported potent antiinflammatory activity of the plant ${ }^{6}$. Analgesic and antiinflammatory of $\beta$-sitosterol isolated from Leaf of $N$. arbortristis has been reported by Nirmal et al. ${ }^{25}$.

\section{Antioxidant activity:}

Amarite et.al reported the antioxidant activity of carotenoid obtained from the plant Nyctanthes arbortristis ${ }^{26}$. Another study conducted on the root extracts to evaluate antioxidant activity by using different in vitro model and revealed that the Pet. Ether and hydroalcoholic extracts showed potent antioxidant activity by reducing power against the standard drug (Kaempferol) ${ }^{27}$. Ethanol and aqueous extract of shoot, seed and leaf of Nyctanthes arbor-tristis (Harsinghar) exhibited the antioxidant activity in DPPH scavenging antioxidant assays. Results revealed that all three aerial parts of Nyctanthes arbor-tristis possess antioxidant activity. Ethanol and aqueous extracts of shoot possessed more antioxidant activity then seed and leaf ${ }^{28}$. The antioxidant activity of leaf extract of this plant has also been reported in another study $^{29}$. The hydroalcohol and chloroform extracts of whole plant of $N$. arbor-trsitis has also been reported to possess strong in-vitro and in-vivo antioxidant activity ${ }^{30}$.
Ghosh et al., identified a water-soluble polysaccharide with potent antioxidant activity from leaves of $N$. arbor-tristis ${ }^{31}$.

\section{Antibacterial activity:}

Harsinghar (N. arbor-tristis) is considered to have antimicrobial activities. Kumar et al., reported that ethanolic leaf extract showed significant antibacterial activity on both Gram +ve and Gram -ve stains. But comparably the activity on $B$. subtilis was more than that of $E$. coli. The antibacterial activity obtained for the leaf extract was significant. The combined leaf extract of Nyctanthes arbor-tristis and Nerium oleander were also conducted in the same study which showed a synergistic effect i.e., antibacterial activity of the Nyctanthes arbor-tristis increased when used with Nerium oleander $^{32}$. Antimicrobial activity of seed and leaf extracts of Nyctanthes arbor-tristis against human pathogens was exhibited in a study using Muller Hinton agar. Seed extract prepared in ethyl acetate had shown positive result on Salmonella typhii and Klebsiella pneumoniae and was less effective on Streptococcus aureus. Ethanol seed extract found effective on E. coli and Streptococcus aureus; hexane seed extract showed promising result with only Klebsiella pneumonia; methanol seed extract was showed significant positive results against Escherichia coli while acetone seed extract was effective against Klebsiella pneumoniae, Streptococcus aureus and Escherichia coli. Diethyl ether seed extract showed positive result only with Streptococcus. 2- Butoxy ethanol seed extract showed positive results on Salmonella and Pseudomonas. Ethyl acetate leaf extract showed antimicrobial activity on Salmonella, Streptococcus and Pseudomonas but showed no effect on Klebsiella and E. coli. The methanol, ethanol, ethyl acetate and acetone extract of leaf showed good results. Leaf extracts showed better zone of inhibition when compared to seed extracts. Hexane leaf and seed extract were found to be least effective. Study concluded that the potent antibiotic property of leaf and seed extract of Nyctanthes arbor-tristis ${ }^{33}$. The antifungal activity of extracts of different parts of (dried leaves, seeds, stem, bark and flowers) of $N$. arbor-tristis plant measured through 'zone of inhibition' of fungal growth was exhibited against three clinical fungal pathogens -Aspergillus niger, Penicillum and Aspergillus flavus. Methanolic extracts from seed, stem, and bark part of the plant showed antifungal activity against all the three species. Distilled water extract of stem and bark showed antifungal activity against $A$. niger; and chloroform extract of leaves only found effective antifungal against $A$. flavus $^{34}$. In another study antifungal activity of nanoparticles of Zinc oxide synthesized on flower extract of N. arbor-tristis and zinc acetate has been reported by Jamdagni et al. ${ }^{35}$. The presence of phytochemicals with adequate antibacterial and antifungal efficacy can be used for the treatment of bacterial and fungal infections. 


\section{Antidepressant activity:}

Tripathi et al. has reported that leaf extract of Nyctanthes arbor-tristis exhibited antidepressant activity ${ }^{36}$. Another study was conducted by Tripathi et al. to evaluate the anxiolytic activity of leaf extract of $N$. arbor-tristis in animal model, and revealed promising results ${ }^{37}$. Das et al. reported that leaf, seed and bark of the N. arbor-tristis are helpful in decreasing dopamine and increasing the serotonin level, depicting CNS depressant activity ${ }^{38}$. In another study in which antidepressant effects of hydroalcoholic leaf extract (250 \& 500 mg/kg) (NTL), flower extract (250 \& 500 mg/kg) (NTF) and combination extract (leaf and flower extract in equal ratio) of Nyctanthes arbor-tristis (NAT) were evaluated viz. forced swim test in animal model. All extracts demonstrated a significant reduction of immobility time. Statistically remarkable differences in immobility time in groups treated with combination extract compared to groups treated with leaf and flower extract alone is observed and study concluded that the hydroalcoholic extracts showed remarkable antidepressant effect ${ }^{7}$ and may help in discovery of new intervention for anxiety and depression.

\section{Antidiabetic activity:}

A study was conducted to investigate the antidiabetic activity of ethanol extract of stem bark of Nyctanthes arbor-tristis L. in streptozotocin (STZ) - nicotinamide induced diabetes in rats and compared with controlled group. Ethanol extract of stem bark of Nyctanthes arbor-tristis was administered orally in diabetic rats. It was found that it significantly lowered the blood glucose level in a dose-dependent manner. In glucose tolerance test, the extracts at the doses of 250 and 500 markedly reduced the external glucose load. The antidiabetic activity of (EENA) was comparable to that of diabetic control drug ${ }^{39}$. In another study, antidiabetic activity of ethanol extracts of aerial stem and leaves of $N$. arbortristis plant was studied subjected to the ethanol extraction using Soxhlet method in rats. The ethanol extract and glipizide provoked a significant fall in the blood sugar level in normoglycemic and glucose loaded rats ${ }^{40}$.

\section{Hypoglycemic and hypolipidemic activity:}

In a study hypoglycemic and hypolipidemic activity of boiled aqueous extract of flowers (AEF) of Nyctanthes arbor-tristis has been reported in mice. Animals were orally administered with $500 \mathrm{mg} / \mathrm{kg}$ and $750 \mathrm{mg} / \mathrm{kg}$ of AEF, and glucose tolerance was performed before and after glucose challenge. In vitro alpha-amylase assay and glucose absorption from the gastrointestinal tract were also performed using $500 \mathrm{mg} / \mathrm{kg}$ of the extract. In addition, glycogen content in the liver and skeletal muscles, a complete lipid profile assay, and toxicological and biochemical parameters were conducted. It was observed that $500 \mathrm{mg} / \mathrm{kg}$ and $750 \mathrm{mg} / \mathrm{kg}$ of AEF significantly reduced fasting blood glucose levels (39\%) respectively at 4 h posttreatment, while $500 \mathrm{mg} / \mathrm{kg}$ of AEF also decreased the random blood glucose level significantly by 32\%. AEF significantly inhibited glucose absorption (85\%) from the intestine and exhibited inhibition of alpha-amylase enzyme activity. It also decreased the level of total cholesterol (44.8\%), triglyceride (53\%) and increased (57\%) the highdensity lipoprotein cholesterol ${ }^{41}$ depicting its hypolipidemic activity.

\section{Anti-proliferative activity:}

In a study, antiproliferative potentials of different fractions (hexane, chloroform, ethyl acetate, methanol) of flower extract of $N$. abor-tristis was shown using 3T3-L1 cells, primary peripheral blood mononuclear cells (PBMC) isolated from healthy and adult acute myeloid (AML) and chronic lymphocytic leukemia (CLL) patients, recombinant Jurkat T cells, and MCF7 cell lines. Inhibition of the 3T3-L1 cells differentiation was observed in the ethyl acetate and chloroform fractions, followed by the hexane fraction. Antiproliferative analyses revealed that Nyctanthes exerted a high specific activity against anti-AML and anti-CLL PBMC cells, especially by the hexane and ethyl acetate fractions, demonstrating the feasibility of $N$. abor-tristis in developing new drug leads against leukemia ${ }^{42}$. In another study phytochemical contents of the plant extracts were investigated for radical scavenging activity and total reducing power of a poly herbal formulation containing leaves of Nyctanthes arbor-tristis, unripe and ripe fruit pulp of Aegle marmelos, and the terminal meristem of Musa paradisiaca flower in the ratio 6:2:1:1 (Poly Herbal Formulation (PHF 1) and 1:1:1:1 (Poly Herbal Formulation (PHF 2). Results revealed that PHF1 exhibited more potent anti-elastase against fibroblasts cells that can be used in reducing the process of skin aging, and PHF 2 found more cytotoxic against malignant melanoma cells ${ }^{43}$.

\section{Anthelmintic activity:}

Ansari et al., reported anthelmintic activity of aqueous, chloroform and acetone, extract of leaves of Nyctanthes arbor-tristis against Indian earth worm Phereima posthuma. The result revealed that all tested extract of Nyctanthes arbortistis shown anthelmintic activity in a dose dependant manner. Among the all extract, acetone extract at $0.5 \mathrm{mg} / \mathrm{ml}$ concentration showed most promising anthelmintic activity ${ }^{44}$.

\section{Antipyretic Activity:}

Harsinghar (N. arbor-trisits) is known for its antipyretic action since centuries ago. A study was carried out to reveal antipyretic activity of $N$. arbor-tristis in various dosage forms. Tablet, liquid oral and suspension dosage forms of dried leaves of Nyctanthes arbor-tristis and dried unripe fruits of Piper nigrum in combination, were tested in Brewer's yeast-induced pyrexia in rabbits. For the purpose, significant values for protection against increasing rectal temperature were observed 
in animals. Study concluded that liquid oral and tablet dosage forms possess good antipyretic property as well as no significant signs of systemic toxicity and death was also noted in Wistar albino rats ${ }^{45}$. In another study, antipyretic activity of whole plant extract of Nyctanthes arbor-tristis has been reported in yeast-induced pyrexia in albino rats ${ }^{46}$. Saxena, et.al reported the analgesic, antipyretic and ulcerogenic activity of Hydroalcoholic extract of leaves of Nyctanthes arbor-tristis ${ }^{47}$. Antipyretic activity and hepatoprotective effect of Petroleum ether and methanol extracts of bark of $N$. arbor-tristis has been reported against Brewer's Yeast induced pyrexia and Carbon tetrachloride (CCl4) induced hepatotoxicity in mice model respectively ${ }^{48}$.

\section{Wound healing activity:}

Wound healing activity in methanolic extract of Nyctanthes arbor-tristis leaves was exhibited on tensile strength of the skin having incision wound in Wistar albino rats. The animals were divided into 3 groups i.e. control, standard and testing group. A full thickness of excision wound of circular area (approx. $500 \mathrm{~mm}^{2}$ and $2 \mathrm{~mm}$ depth was made on back of the anaesthetized rats. The control group was treated with simple ointment base B.P. The standard group was treated with Betadine $5 \%(\mathrm{w} / \mathrm{w})$ ointment. The test group was treated with ointments with methanolic extract of N. arbor-tristis 2 $\%(\mathrm{w} / \mathrm{w})$ incorporated in simple ointment base, for 16 days. Development of granulation tissues in rats treated with ointment containing $2 \%(\mathrm{w} / \mathrm{w})$ methanolic extract exhibiting wound healing activity of $N$. arbor-tristis extract ${ }^{49}$.

\section{CONCLUSION}

Nyctanthes arbor-tristis is a very important medicinal plant and has been used in Unani medicine and folklores for the treatment of number of diseases such as fever, palpitation, jaundice, bronchitis, haemorrhoids, malaria, ringworm, dandruff, etc. Many chemical compounds isolated from the plant and phytochemical analysis demonstrates that due to presence of mentioned phytochemical components the plant is useful in different health problems. It has been very much used for their health care and practices in rural part of India due to its easy accessibility. Botanical and physico-chemical standardization of Habb-e-Harsinghar - A Unani formulation has been carried out by the researchers of Central Council for Research in Unani Medicine to set its standards for quality assurance for global marketing. However, N. arbor-tristis still remains a plant for further research studies. The plant needs to be researched on molecular basis to unmask its potential and more formulations can be proposed and used practically for treatment of several ailments.

\section{REFERENCES}

1. Kabeeruddin M. Ifadah Kabeer Mujmal, Idarah Kitabush-Shifa, New Delhi. 2010, p. 9.
2. Shah M. The General principles of Avicenna's Canon of Medicine, Idara Kitabal-Shifa, New Delhi. 2007, pp. 359, 361 .

3. Qureshi EH. Muqadma Ilmul Advia, Ejaz Publishing House, New Delhi.1995, p. 163.

4. Anonymous. The Unani Pharmacopeia of India, vol. 1 (Part- ${ }^{\text {st }}$ and II), Department of AYUSH, Ministry of Health and Family Welfare, Gov. of India, New Delhi. 2007, pp. 206-215 and part-II p 12.

5. Waseem A, Jamal A, Fazil M. Siras (Albizia lebbeck (L) Benth.) and its Medicinal uses in Unani medicine. CellMed, 2020, 10 (2):pp.12.

6. Omkar A, Jeeja T, Chhaya G. Evaluation of antiinflammatory activity of Nyctanthes arbor-tristis and Onosma echiodes. Pharmacog. Mag. 2006, 8: pp. 25860.

7. Guglani A, Joshi T, and Singh BK. Comparative evaluation of antidepressant activity of various ex tracts of Nyctanthes arbor-tristis. IJPSR June 2019; 10(6): 2806-11.

8. Chopra RN, Nayar SL, Chopra IC. Glossary of Indian medicinal plants, Council of Scientific and Industrial Research, New Delhi. 1956, p. 177.

9. Nadkarni K.M., Nadkarni A.K. Indian Materia Medica, Vol II, Popular Prakashan Pvt Ltd. Bombay. 1976, pp. 857-858.

10. Dymock W, Warden, CJH, and Hooper D. Pharmacographia Indica, Vol. II, M/S Bishen Singh Mahendra Pal Singh, Connaught Place, New Delhi. 1891, pp. 376-77.

11. Kabiruddin M. Makhzan al-Mufradat, Sheikh Mohd. Basheer and Sons, Urdu Bazaar, Lahore. YNM, pp. 587.

12. Shirazi MMH. Makhzan al-Advia, Matba Ahmadi, Delhi. 1278, pp. 638-639.13. Sharma L, Dhiman M, Singh A, et al. Nyctanthes arbor-tristis L., An Unexplored Plant of Enormous Possibilities for Economic Revenue, Proceeding of National Academy of Science., India, Section B: Biological Sciences. 2021, 91, pp. 241-255.

14. Ghani MN. Khazain al-Advia, Vol. 6, CCRUM, New Delhi. 2010, pp.510-11.

15. Khan MS. Taleef Sharifi, Akmal al-Mat'aba, Delhi.1880, pp. 214-215.

16. Anonymous. Medicinal Plants of folklores of Northern India, Central Council for Research in Unani Medicine, New Delhi. 2001, pp. 358-359.

17. Tripathi A, Kumar S, Srivastava SK. Medicinal Properties of Harsingar (Nyctanthes arbor-tristis 
Linn.): A Review. IJCRT. January 2021, Volume 9, Issue 1, pp.3406-10.

18. Khan MA. Muheet-i Azam. Vol. IV. CCRUM, New Delhi. 2018, pp. 899-900.

19. Nabi MG. Makhzan Al-Mufadaat wa Murakkabat, CCRUM, New Delhi. 2007, p. 245.

20. Saikia B, Saikia N. Medico-ethnobotany of Bodo tribals in Gohpur of Sonitpur district, Assam. Indian journal of traditional knowledge. 2008; 9(1): 52-54.

21. Rathee JS, Hassarajani SA, Chattopadhyay S. Antioxidant activity of Nyctanthes arbor-tristis leaf extract. Food Chem. 2007; 103:1350-57.

22. Anonymous. The Wealth of India 1997, Wealth of India, a Dictionary of Indian Raw Materials and Industrial Products. National Institute of Science Communication, CSIR, New Delhi. 1997, Vol. 7: pp. 69-70.

23. Saxena RS, Gupta B, Lata SJ. Tranquilizing, antihistaminic and purgative activity of Nyctanthes arbor-tristis leaf extract. Journal of Ethnopharmacology. 2002, Aug 81(3): pp. 321-25.

24. Saxena RS, Gupta B., Saxena KK, Singh RC, Prasad DN. Study of anti-inflammatory activity in the leaves of Nyctanthes arbor-tristis Linn. -an Indian medicinal plant, Journal of Ethnopharmacology. 1984, 11(3):31930.

25. Nirmal SA, Pal PC, Mandal SC, Patil AN. Analgesic and anti-inflammatory activity of $\beta$-sitosterol isolated from Nyctanthes arbor-tristis leaves. Inflammopharmacology. 2012;20: 219-224.

26. Amarite O, Bhuskat P, Patel N, Gadgoli C. Evaluation of antioxidant activity of carotenoid from Nyctanthes arbortristis, Int J Pharmacol Biol Sci. 2007; 2:57-59.

27. Das SS, Paul A, Abdullah, Samim A. Antioxidant Activity of hydro-alcoholic Extract on the Roots of Nyctanthes arbor-tristis, International Journal of Current Pharmaceutical Research, 2018 (Jul-Aug); Vol. 10 (4): pp. 51-54.

28. Patel S, Gokhale M. Comparative Study of Antioxidant Activity of Ethanol and Aqueous Extracts of Different Parts of Nyctanthes arbor-tristis Linn, Pharmacognosy Journal, December 2016; 8 (2): pp. 113-116.

29. Rathee JS, Hassarajani SA, Chattopadhyay S. Antioxidant activity of Nyctanthes arbor-tristis leaf extract. Food Chem. 2007; 103: pp.1350-57.

30. Dahiya RS, Kaur P, Kashyap P, Katoch N, Gupta S: Pharmacological evaluation of hydroalcohol and chloroform extracts of Nyctanthes arbor-tristis for antioxidant, anti-inflammatory and analgesic activity.
International Journal of Pharmacy and Pharmaceutical Sciences. 2014; 6(9): pp. 460-465.

31. Sundaram IK, Sarangi DD, Sundararajan V, et al. Polyherbal formulation with anti-elastase and antioxidant properties for skin anti-aging. BMC Complement Altern Med. 2018 Jan 29;18(1): pp. 33.

32. Kumar AR, Phani CHSD, Yadav D. Antibacterial activity of ethanolic extracts of Nyctanthes arbortristis and Nerium oleander. Indian Journal of Research in Pharmacy and Biotechnology. 2013; Vol.1(3): pp. 310313.

33. Prasad MP, Shekhar S. In-Vitro Phytochemical and Antimicrobial activity of Nyctanthes arbortristis Linn against human pathogens. Int. J. Pure App. Biosci. 2014; 2 (1): pp. 1-5.

34. Verma L, Tamrakar V, Haque N, Kumar A. Antifungal activity of different extracts from different parts of $N$. arbor-tristis was evaluated against clinical pathogens. Shodh Darpan. 2016 Vol.1 (4): 239-250.

35. Jamdagni P, Khatrip, Rana JS. Green synthesis of zinc oxide nanoparticles using flower extract of Nyctanthes arbor-tristis and their antifungal activity. Journal of King Saud University-Science. 2018, Vol. 30(2):168175 .

36. Tripathi S, Tripathi PK, Singh PN. Antidepressant activity of Nyctanthes arbor-tristis leaf extract. Pharmacology Online. 2010; 3: 415-22.

37. Tripathi S, Tripathi PK, Singh N. Anxiolytic activity of leaf extracts of Nyctanthes arbor-tristis in experimental rats. Pharmacology Online. 2010; 2: 18693.

38. Das S, Sasmal D, Basu SP. Evaluation of CNS depressant activity of different parts of Nyctanthes arbor-tristis. Indian Journal of Pharmaceutical Science. 2008; 70; pp. 803- 06.

39. Suresh V, Jaikumar S, Arunachalam G. Antidiabetic activity of ethanol extract of stem bark of Nyctanthes arbor-tristis Linn, Research Journal of Pharmaceutical. Biological and Chemical Sciences. 2010, Vol.1 (4); pp.311-317.

40. Gharti KP, Buddhi CB, Bharati M, Bharati L. Antimicrobial and anti-diabetic activity of nyctanthes arbortristis. World Journal of Pharmacy and Pharmaceutical science. 2020,

41. Rangika BS, Dayananda PD, Peiris DC. Hypoglycemic and hypolipidemic activities of aqueous extract of flowers from Nyctanthes arbor-tristis L. in 
male mice. BMC Complement Altern Med. 2015 Aug 19;15:289. doi: 10.1186/s12906-015-0807-0.

42. Heendeniya SN, Keerthirathna LR, et al. Therapeutic Efficacy of Nyctanthes arbor-tristis Flowers to Inhibit Proliferation of Acute and Chronic Primary Human Leukemia Cells, with Adipocyte Differentiation and in Silico Analysis of Interactions between Survivin Protein and Selected Secondary Metabolites. Biomolecules. Jan 2020; 10 (2): 165.

43. Sundaram IK, Sarangi DD, et. al. Polyherbal formulation with anti-elastase and anti-oxidant properties for skin anti-ageing, BMC Complement Altern Med. 2018 Jan 29;18(1): pp.33

44. Ansari IA, Patil JK, Kamora KR, et. al. Anthelmintic activity of Nyctanthes arbor-tristis leaves on Indian earth worms. Indian Journal of Drugs. 2016, 4(2): pp. 63-68.

45. Ghiware NB, Nesari TM. Antipyretic Activity of Piper nigrum and Nyctanthes arbor-tristis in Different Dosage
Forms. Research J. Pharm. and Tech. 2010, 3 (1): pp. 157-160.

46. Shirsat MK, Gupta SK, et al. Antipyretic Effects of Whole Plant Extract of Nyctanthes arbortristis Linn. A Journal of Pharmaceutical Science. 2011, Vol. 2(1): 710.

47. Saxena RS, Gupta B, Saxena KK, Srivastava VK, Prasad DN. Analgesic, antipyretic and ulcerogenic activity of Nyctanthes arbor-tristis leaf extract. Journal of Ethnopharmacology.2017;19 (2):193-200.

48. Singha S, Bawari M, Choudhury MD. Hepatoprotective and antipyretic effect of bark of Nyctanthes arbor-tristis Linn. International Journal of Pharmacy and Pharmaceutical Sciences. 2014, Vol. 6 (2): pp. 110-114.

49. Bharti M, Saxena RC, Baghel OS, Saxena R, Apte KG. Wound healing activity of leaf of Nyctanthes arbortrisitis Linn. International Journal of Pharmaceutical Sciences and Research. 2011 oct; pp. 2694-2698. 